\title{
EKSISTENSI MODEL PERGURUAN TINGGI DI LINGKUNGAN PONDOK PESANTREN (STUDI TENTANG PELUANG DAN TANTANGANNYA DI ERA 4.0)
}

\author{
Mustopa $^{1}$, Ahmad Hapidin ${ }^{2}$, Jagad Rayana ${ }^{3}$, Asep Deni Adnan Bumaeri ${ }^{4}$, Hisam Ahyani ${ }^{5}$ \\ ${ }^{1,2,3,4}$ Sekolah Tinggi Ilmu Syariah Wal Aqidah Ash-Shofa Manonjaya, ${ }^{5}$ Sekolah Tinggi Agama Islam \\ Miftahul Huda Al Azhar Banjar \\ Jl. Cihaur No. 18 Desa Kalimanggis, Kabupten Tasikmalaya, Jawa Barat \\ e-mail: cipakumustopa@gmail.com, ahapidin@gmail.com, kuncup_20@yahoo.com, Asden1071@gmail.com, \\ hisamahyani@gmail.com
}

\begin{abstract}
Abstrak: Model pendidikan tinggi di lingkungan pondok pesantren memang menjadi sesuatu yang baru dalam dinamika pendidikan Islam. Eksistensinya pun semakin dinamis di tengah era 4.0, tentu ada peluan dan tantangan yang di hadapi. Penelitian ini bertujuan untuk 1) menganalisis model perguruan tinggi yang ada di lingkungan pesantren dalam mengimplementasikan pendidikan di era 4.0. 2) menganalisis strategi yang di gunakan oleh pesantren untuk menjaga eksistensi perguruan tinggi 3) menganalisis peluang dan tantangan yang dihadapi perguruan tinggi yang berada di lingkungan pesantren. Metode penelitian yang digunakan adalah library research. Hasil penelitian ditemukan bahwa di era 4.0 melalui berbagai model yang ditawarkan dalam mempertahankan eksistensinya adalah memperkuat manajemen, tata kelola, dan sumber daya manusia tanpa menghilangkan tradisi, budaya, kurikulum yang ada di pesantren yang menaungi perguruan tinggi tertentu. Selain itu dapat dilakukan dengan cara melakukan inovasi-inovasi dalam rangka mempertahankan kualitas perguruan tinggi semisal pemanfaatan media pembelajaran berbasis digital bagi mahasiswa. Peluang yang dimiliki yakni kebijakan pemerintah yang memihak, model pendidikan yang sesuai dengan tuntutan zaman, sumber daya manusia yang mumpun. Tantangannya seperti tuntutan perkembangan teknologi, penyesuaian kurikulum, dan menolak perubahan.
\end{abstract}

Kata Kunci: Pondok Pesantren, Era 4.0, Peguruan tinggi,

\begin{abstract}
The model of higher education in Islamic boarding schools has indeed become something new in the dynamics of Islamic education. Its existence is even more dynamic in the midst of the 4.0 era, of course there are opportunities and challenges to be faced. This study aims to 1) analyze the model of higher education in the pesantren environment in implementing education in the 4.0 era. 2) analyze the strategies used by Islamic boarding schools to maintain the existence of universities. 3) analyze the opportunities and challenges faced by universities in the pesantren environment. The research method used is library research. The results of the study found that in the 4.0 era through various models offered in maintaining its existence, it was to strengthen management, governance, and human resources without losing the traditions, culture, curriculum in Islamic boarding schools that oversee certain universities. In addition, it can be done by making innovations in order to maintain the quality of higher education, such as the use of digital-based learning media for students. Opportunities that are owned are government policies that take sides, educational models that are in accordance with the demands of the times, qualified human resources. The challenges are the demands of technological developments, curriculum adjustments, and resisting change.
\end{abstract}

Keywords: Higher Education, Islamic Boarding School, Existence, Era 4.0 
Hikmah, Vol. 18, No. 1, Januari-Juni 2021, p-ISSN: 1829-8419 e-ISSN: 2720-9040

\section{PENDAHULUAN}

Dewasa ini dengan semakin berkembangnya zaman yang selalu maju (berubah-ubah) karena termakan zaman, dunia pendidikan khusunya di era disrupsi seperti sekarang ini, pesantren banyak melakukan perubahan atau transformasi model pendidikan, salah satunya adalah mensinergikan model pendidikan yang ada di Pondok Pesantren sebagai wujud tetap mengudaranya dunia pendidikan melalui transformasi pesantren di era yang serba digital seperti sekarang ini.

Dewasa ini di era 4.0 yang serba canggih dalam risetnya menjelaskan bahwa ada tranformasi yang dilakukan oleh pesantren dalam rangka mengembangkan budaya bangsa Indonesia dalam bidang pendidikan yang sekarang berniat mentransformasikan dirinya (pesantren) melalui berbagai transformasitransformasi pendidikan yang dianggap jitu mampu menjawab tantangan di era 4.0 diantaranya dengan melalui penguasaan bahasa asing oleh pihak pesantren, kemudian melakukan sebuah trik market (kewirausahaan) dan pemanfaatan ICT (information and Communication Technology, yang mana ketiga model transformasi ini masuk pada ranah modernisasi (merubah dari klasik ke modern yang lebih baik) (Athoillah and Wulan 2019).

Selain itu adaptasi tersebut sangat terlihat dari pada pengapdopsian yang dilakukan oleh pesantren dari kurikulum agama kedalam kurikulum nasional sehingga pesantren dewasa ini menjadi pesantren yang modern karena termakan zaman, yang mana hingga kini di era 4.0 psesantren-pesantren yang ada di Indonesai khusunya menggabungkan mata pelajaran yang eksak dan non eksak (ilmu agama dengan ilmu umum) dalam kurikulum pesantren, serta upaya yang dilakukan oleh peantren guna mengejar ketertinggalan zaman pesantren di Indonesia melakukan sebuah trik jitu yakni mengintegrasikan dengan cara yang dinamis pada kurikulum yang ada di pesantren kedalam sistem pendidikan nasional (Isbah 2020).

Selanjutnya dengan mengacu pada UU no. 20 Tahun 2003 tentang sitem pendidikan nasional, perlu adanya gencatan senjata yang dilakukan oleh para calon cendikia muslim dimana dengan adanya mandat UU pendidikan tersebut eksistensi daripada dunia kepesantrenan di era disrupsi seperti sekarang ini wajib memiliki daya tahan serta perwujuan salah satunya dengan cara tetap melanggengkan kehidupan dunia pesantren khusunya di Indoenesia (Manan 2019).

Dengan demikian hadirnya era revolusi 4.0 seperti sekarang ini, maka model perguruan tinggiyang disinergikan kedalam pesantren dewasa ini patut di apresiasi karena tuntutan zaman yang begitu cepat. Biasanya pesantren jika tidak ada lembaga formalnya semisal (sekolah menengah atas, Sekolah menengah pertama, dan sekolah dasar/madrasah) pesantren tersebut dianggap kurang menarik alias kurang peminatnya. Begitupun di lingkup perguruan tinggi, ketika dunia kampus disinergikan kedalam dunia kepesantrenan maka jatuhnya pun akan menjadi ambiguitas sistem pendidikannya, contohnya jika ada kegiatan tertentu baik di pesantren maupun di kampus yang ditempati, maka manakah yang harus didahulukan ?, untuk menjawabnya maka perlu adanya kajian khusus yakni bagimana model perguruan tinggi yang ada di lingkungan pesantren dalam menerapkan model pendidikannya di era 4.0 seperti sekarang ini ?. Kemudian perlu juga dikaji terkait bagaimana pesantren menjadikan tetap eksis dalam mencerdaskan kehidupan bangsa melalui pendidikan ?. Dan apa saja peluang dan tantangan yang dihadapi dalam penerapan model pendidikan perguruan tinggi yang berada di lingkungan pesantren ?. Dari arah kajian diatas, maka peneliti berusaha menguak serta menggali terkait Eksistensi Penerapan Model 
Perguruan Tinggi Di Lingkungan Pondok Pesantren Pada Era 4.0.

Pentingya kajian riset ini yakni dimana Era 4,0 seperti sekarang ini perlu adanya Inovasi serta strategi yang di lakukan oleh perguruan tinggi dalam mempertahankan eksistensinya terlebih di masa Pandemi Covid-19.

\section{METODE PENELITIAN}

Metode penelitian dalam kajian ilmiah penelitian ini peneliti menggunakan studi kepustakaan (library research)(Ahyani and Muharir 2021, 0). Dengan sumber data yang digunakan berasal dari sumber-sumber perpustakaan atau dokumentasi-dokumentasi tentang kepesantrenan dan perguruan tinggi yang ada di Indonesia. Adapun kajian sumber data peneliti peroleh dari sumber-sumber utama (primer) yang berasal dari literatur-literatur (Tabroni, Ahyani, and Permana 2021). Literatur ini yang berkaitan dengan tema "perguruan tinggi dan pesantren dan juga era 4.0) atau revolusi Industri 4.0 (disrupsi). Dalam Pengolahan data dalam riset penelitian ini, peneliti menggunakan metode penelitian yang bersifat deskriptif-analitis (Ahyani, Muharir, and Permana 2020), dimana model penelitian yang digunakan berupaya mendeskripsikan, dan mencatat, serta menganalisa, dan juga menginterpretasikan pada ranah fenomenafenomena yang ada (di perguruan tinggi dan di pesantren) sehingga diharapkan memberi deskripsi kepada perguruan tinggi dan juga lembaga pesantren dalam mensikapi bagaimana perilaku masyarakat sekarang dalam menjawab tantangan pendidikan di era revolusi industri 4.0 seperti sekarang ini.

\section{HASIL DAN PEMBAHASAN}

Kebaruan Penelitian ini yakni terkait Eksistensi Model Perguruan Tinggi Di Lingkungan Pondok Pesantren Di Era 4.0, semisal Perguruan Tinggi Islam Swasta yang ada di Kota Banjar Jawa Barat yaitu STAI Miftahul Huda Al Azhar (STAIMA) Kota Banjar yang berada di lingkungan Pondok Pesantren Miftahul Huda Al Azhar Citangkolo (YaMAC) Kota Banjar Provinsi Jawa Barat; Selanjutnya STITNU Al Farabi Pangandaran, Provinsi Jawa Barat yang berada di Lingkungan Yayasan Pondok Pesantren Babakan Jamanis Parigi, Kabupaten Pangandaran Provinsi Jawa Barat; dan Sekolah Tinggi Ilmu Syariah Wal Aqidah (STISA) Ash-Shofa Manonjaya, Tasikmalaya, Provinsi Jawa Barat.

\section{Model Perguruan Tinggi di Lingkungan Pondok Pesantren}

Ada berbagai model pendidikan tinggi di Indonesia, diantaranya adalah meliputi universitas, insititut, sekolah tinggi, politeknik, dan akademi (Harususilo 2021). Mengacu pada UU No. 12 Tahun 2012 mengenai Pendidikan Tinggi dijelaskan bahwa pendidikan tinggi sebagai bagian dari pada sebuah sistem pendidikan nasional yang mempunyai peranan yang strategis dalam rangka mencerdaskan kehidupan bangsa dan dalam rangka memajukan ilmu pengetahuan serta teknologi dengan melihat serta memperhatikan dan juga menerapkan nilai humaniora (kemanusiaan) serta pembudayaan dan juga pemberdayaan suatu bangsa yang terus mengalami kontinuitas yang tinggi. Lebih lanjut dalam Pasal 1 pont 2) UU No. 12 tahun 20212 ini bahwa Pendidikan Tinggi merupakan jenjang pendidikan setelah pendidikan menengah yang cakupannya adalah program diploma, sarjana, magister, doktor, dan juga program profesi, serta ada juga program spesialis, yang dapat diselenggarakan oleh perguruan tinggi yang berdasarkan pada kebudayaan masyarakt/bangsa Indonesia.

UU Nomor 18 Tahun 2019 menjelaskan tentang Pondok Pesantren, Dayah, Surau, Meunasah, yang mana kesemuanya ini disebut dengan Pesantren merupakan sebuah lembaga 
yang berbasis masyarakat dan didirikan oleh perseorangan, atau bisa juga dari yayasan, atau dapat juga didirikan oleh organisasi masyarakat (ormas) Islam, atau juga dapat dibentuk oleh masyarakat yang tujuannya adalah menanamkan keimanan serta ketaqwaan di sisi Alloh Swt, dan membentuk akhlak mulia danmemegang teguh ajaran Islam yang rahmatan lil'alamin yang tercermin dari sikap rendah hati, toleran, keseimbangan, moderat, dan nilai luhur bangsa Indonesia lainnya melalui bidang pendidikan, dakwah Islam, keteladanan, dan pemberdayaan masyarakat dalam kerangka Negara Kesatuan Republik Indonesia (Pasal 1 point 1) UU No.12 tahun 2019 tentang Pesantren).

Pesantren menurut (Nizar 2013; Darwis $2020,1)$ yaitu salah satu lembaga pendidikan Islam tradisional yang tumbuh dan berkembang di tengah-tengah masyarakat. Pesanten juga memiliki tujuan untuk ikut mencerdaskan bangsa Indonesia, yang mana dari dulu hingga sekarang pesantren selalu memberikan kontribusi yang cukupbesar dalam kegiatan pendidikan di Indonesia. Selain itu, pesantren merupakan lembaga pendidikan Islam tradisional yang bertujuan untuk mengajari dan mengamalkan ajaran-ajaran Islam yang menekankan pada pentingnya moral agama dalam berkehidupan di masyarakat. Dari penjelasan diatas maka dapat disimpulkan bahwa dalam penelitian ini bahwa perguruan tinggi yang dimaksud adalah perguruan tinggi yang berada di sekitar wilayah lokasi pesantren, baik berdekatan maupun dibawah naungan pesantren. Sehingga model pendidikan pesantren yang eksis di tengahtengah masyarakat ini tantangan yang dihadapi di era 4.0 seperti sekarang perlu dikaji guna mengetahui trik apa saja yang dilakukan oleh dunia pendidikan yang katakanlah berbasis pesantren di era yang serba digital seperti sekarang ini dalam mempertahankan eksistensinya dalam rangka mencerdaskan kehidupan bangsa sesuai amanah yang ada pada UU 1945.

\section{Era Revolusi Industi 4.0}

Revolusi Industri 4.0 mendapat perhatian dari Lembaga Pendidikan Tinggi di seluruh dunia. Untuk itu penting untuk mengundang para Masyarakat yang ada di Indonesia untuk melakukan evaluasi diri, mengapa berbagai permasalahan seperti halnya kemiskinan, kesenjangan, deforestasi, dan pengrusakan tanah, dan juga tuntutan zaman revolusi era keempat industri (Industri 4.0) yang akan menciptakan pengangguran, serta berpotensi pada ranah perluasan dalam hal kesenjangan ekonomi (Aryati 2019, 4). Dalam riset yang dilakukan oleh (Nurcholiq 2019) ditemukan bahwa era revolusi industri (4.0) dapat dikatakan suatu zaman yang menekankan pada pola digital economy (ekonomi digital), artificial intelligence (Kecerdasan yang dibuatbuat/buatan), big data (maha data/himpunan data yang sangat besar), robotic (program robot) artinya pekerjaan manusia secara fisik dapat diganti dengan robot), atau yang biasa dikenal dengan fenomena-fenomena disruptive innovation (inovasi-inovasi disrupsitf).

\section{Implementasi Penerapan Model Perguruan Tinggi Di Lingkungan Pondok Pesantren pada Era 4.0}

Dalam dinamika yang terus selalu mengalami prosesi perkembangan dalam peneyelelnggaraan pendidikan tinggi di Indonesia yaitu sebuah proses dan pengembangan dalam penyelenggaraan Program Studi di Luar Kampus atau disingkat (PSDKU) yang dicanangkan oleh kampus Universitas Padjajaran bandung (Unpad) di wilayah Pangandaran Jawa Barat, dan tingkat kepuasan mahasiswa terhadap PSDKU Unpad di Pangandaran berada dalam kategori puas. Bahwa program PSDKU Unpad Pangandaran 
seharusnya dikelola dengan manajemen perguruan tinggi yang khusus, yaitu dengan memberikan otonomi pengelolaan dalam bidang keuangan (Sukoco, Fordian, and Rusdin 2019).

Model pendidikan perguruan tinggi yang ada di wilayah Jawa barat diantaranya peneliti melihat serta mengamati dilapangan bahwa pesantren yang membuka perguruan tinggi di lingkungan pesantrennya rata-rata dapat meningkatkan kuantitas santrinya dalam sekala jumlah santri, dimana rata-rata para santri dengan sendirinya berbaur dengan teknologi semisal Mursid membuat sebuah catatan khusus untuk artikel dan pemasaran bisnis kecil-kecilan berupa jual beli buku, kaos, desain grafis, video tutorial-tutorial tentang keagamaan, dan lain sebagainya. Mursid biasa yang merupakan salah atu mahasiswa STAI Miftahul Huda Al Azhar Banjar, Jawa Barat juga selain mondok di Pesantren Miftahul Huda Al Azhar Citangkolo Kota Banjar Jawa Barat juga memiliki usaha kecil-kecilan berupa jasa pembuatan, penjualan kaos-kaos tertentu sesuai dengan permintaan pelanggan. Pesantren lainnya Pondok Pesantren Miftahul Huda Kalimanggis Manonjaya Tasikmalaya yang mendirikan Sekolah Tinggi Ilmu Syariah Wal Aqidah Ash-Shofa Manonjaya, Indonesia, tepatnya beralamat di Jalan Cihaur No. 18 Desa Kalimanggis Kecamatan Manonjaya Kab. Tasikmalaya Prov. Jawa Barat Indonesia, juga menjadikan para yang unggul dalam pendidikan. Pihak pengurus pesantren kemudian memodifikasi cara pengajarannya dengan memberlakukan rujukan kurikulum terdahulu yaitu kurikulum tahun 1979 yang menjadi pola dasar dalam pendidikan di ponpes Miftahul Huda Manonjaya dengan mengembangkan RPP, target dan capaian dari pola dasar yang dikembangkan sehingga lebih mudah diterima oleh para santri. Selain itu Pesantren tersebut menargetkan dalam jangka waktu 10 Tahun "Mondok Lulus Bergelar Sarjana"(Rukanda 2021).
Pondok pesantren menjadi sebuah lembaga pendidikan Islam yang secara tradisional telah tumbuh dan berkembang di tengah-tengah masyarakat. Seiring dengan perkembangan zaman, pondok pesantren tradisional berubah menjadi pondok pesantren modern dengan tidak meninggalkan agama sebagai pijakannya. Salah satunya pesantren tradisional yang berkembang menjadi pesantren modern yaitu pondok Pesantren Miftahul Huda Manonjaya, Kabupaten Tasikmalaya. Alhasil pesantren sekarang sebagaimana riset ilmiah yang dicanangkan oleh Adeng, di tahun 20211 ini tidak hanya mengajarkan ilmu keagamaan saja tetapi ilmu pengetahuan dan juga ilmu-ilmu masalah keduniawian (bisnis, berwirausaha, dll). Oleh karena itu, pondok Pesantren Miftahul Huda mempunyai tiga peranan penting, yang dijadikan sebagai lembaga pendidikan Islam, yaitu meliputi pengembangan sumber daya manusia, dan juga pengembangan masyarakat (Adeng 2011).

Model Perguruan Tinggi di Lingkungan Pondok Pesantren lainnya adalah Sekolah Tinggi Ilmu Tarbiah Nahdaul 'Ulama Al Farabi Pangandaran dengan program studi Manajemen Pendidikan Islam dan Pendidikan Islam Anak Usia Dini, hingga kini menjadi kekuatan bagi masyarakat dalam mengelola pendidikan di wilayah bagian Kabupaten Pangandaran. Minat masyarakat pada Manajemen Pendidikan sangat tinggi, hal ini dapat dibuktikan dengan tinggi permohonan masyarakat dalam penyelenggaraan seminar dan workshop dalam bidang manajemen pendidikan islam dalam bidang pendidikan. Selain itu, Pendidikan Islam Anak Usia Dini, tidak hanya menyentuh pendidikan formal maupun non-formal namun juga pendidikan informal. Pendidikan keluarga, pendidikan tentang perempuan, anak-anak, keluarga, baik melaui seminar, workshop, pengajian, sosialisasi, STITNU juga terus diminta dan diminati oleh masyarakat melaui 
Hikmah, Vol. 18, No. 1, Januari-Juni 2021, p-ISSN: 1829-8419 e-ISSN: 2720-9040

prgram smart parenting.

Dalam hal ini, STITNU Al Farabi Pangandaran bersamasama masyarakat di lingkungan pesantren mewujudkan Nawacita Presiden Republik Indonesia (stitnualfarabi.ac.id 2021). Kampus tersebut telah melakukan kerjasama-kerjasama, salah satunya dengan KPU Kabupaten Pangandaran, dalam Kerjasama dengan KPU tersebut dalam rangka upaya peningkatan partisipasi masyarakat dalam proses demokrasi pemilu maupun pemilihan di masa yang akan datang (Pangandaran 2021). Dimana STITNU Al Farabi Pangandaran ini berada di lingkungan pesantren Babakan Jamanis Parigi Pangandaran yang sangat strategis, dimana pesantren ini berada di Jl. Raya Parigi Cigugur Karangbenda, Parigi, Pangandaran, Jawa Barat yang senantiasa mengedepankan Manajemen Strategik Pemasaran Pendidikanberbasis Media Sosial. Dimana manajemen strategi pemasaran dalam dunia pendidikan yang berbasis media sosial yang dapat digunakan diantaranya berupa facebook, instagram, dan youtube dengan mengidentifikasi terlebih dahulu di lingkungan masyarakat yang kemudian menjadi strategi pemasaran pendidikan dengan menonjolkan prestasi lembaga tersebut. Pengelolaan pendidikan yang bersifat swasta, didukung dengan stakeholders dan fasilitas yang mendukung telah memberikan ciri khas dan kekuatan pada manajemen strategi pemasaran pendidikan di Madrasah Aliyah yang berada di bawah naungan Yayasan Pondok Pesantren Babakan Jamanis (Nurmalasari and Masitoh 2020a).

Artinya pendidikan ditingkat SLTA pun seperti Madrasah Aliyah Yayasan Ponpes Babakan Jamanis Parigi Pangandaran dapat melakukan transformasi pemasaran melalui media sosial yang mana di era 4.0 seperti sekarang ini dituntut untuk selalu berbaur dengan yang namanya gadjet (Nurmalasari and
Masitoh 2020b). Begitupun model pendidikan tinggi yang ada di Kota banjar Jawa barat yaitu STAIMA Kota Banjar dimana pemasarannya pun menggunakan media sosial. Selain itu STAIMA Kota Banjar atau Sekolah Tinggi Agama Islam Miftahul Huda Al Azhar (STAIMA) Kota banjar sebagai perguruan tinggi yang berada di lingkungan pesantren menawarkan sebuah konsep pembelajaran dengan mamanfaatkan fitur-fitur yang ada pada aplikasi tertentu semisal pada aplikasi SIAKAD dalam rangka memenuhi kebutuhan zaman yang serba digital seperti sekarang ini (Sevima 2018). Siakad ini bertujuan mempermudah dalam hal pengelolaan perguruan tinggi yang notabene perguruan tinggi islam swasta ini berada di lingkungan pesantren Miftahul Huda Al Azhar Citangkolo Kota Banjar, Jawa Barat. Hal ini juga sangat menunjang tekad dalam rangka membangun STAIMA Kota Banjar menuju Global Vision With Local Action yaitu menjadikan visi kampus menuju global (nasional/internsional) dengan Aksi Lokal/wilayah dengan upaya meningkatkan kualitas dan mutu pendidikan sesuai kebutuhan yang ada di lingkungan masyarakat, sehingga kedepannya STAIMA Kota Banjar juga akan beralih status menjadi pusat keilmuan yaitu menuju Universitas Miftahul Huda Al Azhar.

Selain itu pendidikan islam dalam lingkup multikultural juga dikedepankan dimana pesantren dan perguruan tinggi saling mengkombinasikan antar keduanya tanpa menghilangkan tradisi pesantrennya (D. Permana and Ahyani 2020). Selain pendidikan dengan Model pembelajaran klasik di pesantren yang harus dilakukan oleh pesantren, Pesantren melalui kegiatan keagamaan lainnya juga perlu ditanamkan guna menjaga moral (akhlak) santri tetap unggul, yang mana pendidikan moral dapat diimplementasikan melalui kegiatan Thoriqoh Naqsabandiyah Kholidiyah di lingkuungan pondok pesantren (D. D. Permana 
2011). Hal lainnya yang tidak kalah penting adalah gagasan yang dilakukan oleh para pendiri pesantren yang mana dalam rangka ikut berkontribusi di dunia pendidikan nasional pesantren berinisiatif untuk menggagas model perguruan tinggi yang berbasis pesantren, dewasa ini menjadi keniscayaan dimana PTAI (perguruan tinggi agama islam) berbondongbondong melakukan sebuah transformasi pendidikan dengan mencetak generasi masa depan yang unggul salah satunya dengan mendirikan perguruan tinggi islam yang berbasis pesantren (Setyawan 2017).

\section{Peluang dan Tantangan Model Perguruan Tinggi di Lingkungan Pondok Pesantren pada Era 4.0}

Peluang penerapan Model Perguruan Tinggi yang berada di Lingkungan Pondok Pesantren pada Era 4.0 dengan melihat bahwa dalam hal ini (pendidikan), Pemerintah telah memberikan kontribusi serta perhatian melalui Undang-Undang yang dicanangkannya yaitu pada UU No. 20 tahun 2003 yang diperkuat juga dengan PP. No. 55 tahun 2007 tentang Pendidikan Agama dan Pendidikan Keagamaan. Dalam hal ini peraturan pemerintah tersebut dijelaskan eksistensi bahwa pesantren dalam pasal 26, dejelaskan bahwa "Pesantren menyelenggarakan pendidikan dengan tujuan menanamkan keimanan serta ketaqwaan kepada Alloh SWT, akhlak mulia, serta tradisi pesantren dalam rangka mengembangkan kemampuan, serta pengetahuan, dan juga keterampilan bagi peserta didik untuk menjadi ahli ilmu agama Islam (mutafaqqih fiddin) dan / atau menjadi muslim yang memiliki keterampilan / keahlian untuk membangun kehidupan yang Islami di lingkungan masyarakat.

Peluang lainnya sebagaimana riset yang dicanangkan oleh (Shofiyyah, Ali, and Sastraatmadja 2019) bahwa dalam Arus globalisasi seperti di zaman yang serba canggih ini di era milenial mampu membuat generasi menjadikan perubahan karakteristik khusus, dimana msyarakat (muda, tua, anak-anak) yang tidak dapat jauh dari apa yang disebut smart phone atau lebih tepatnya dalam hal penggunaan teknologi, semisal pemanfaatan internet, medoso (media sosial) dana masih banyak yang lainnya. Hal inilah yang menjadikan sebuah lembaga pondok pesantren, mau tidak mau harus melakukan modernisasi dalam rangka memenuhi kebutuhan yang sekarang masyarakat "generasi milenial" menjadi lebih maju karena zaman yang telah datang pada waktunya. Modernisasi ini dapat dilakukan dengan mudah dengan berbagai cara, semisal dengan melihat kebutuhan "pangsa pasar" yang ada, dimana pasar membutuhkan SDM/sumber daya manusia yang mampu bersaing di era 4.0 seperti sekarang ini. Maka dari itu niscaya muncullah model-model lembaga pondok pesantren di era milenial karena zaman yang sudah berubah. Berbagai pengembangan yang ada dan ini terus dilakukan, diantaranya dapat memanfaatkan adanya kursus bahasa inggris misalnya dalam menjawab tantangan di masa yang akan datang. Selain itu keirausahaan atau entrepreneurship, dan juga Information and Communication Technology (ICT) juga menjadi hal yang biasa dilakukan oleh pesantren. Hal ini tentu memberi dampak yang positif bagi lembaga pesantren. Namun perlu diingat bahwa pesantren dimasa mendatang itu perlu membuat sebuah gebrakan yang unik dalam menjawab tantangan era 4.0 dimana tantangan terbesarnya adalah menjadikan lemahnya fungsi pokoknya (tufoksi) sebuah lembaga pesantren yaitu menghasilkan manusia-manusia tafaquhfiddin (ahli agama islam). Oleh karena itu pesantren harus mampu mengkaji ulang secara tepat dan cermat serta berhati-hati dalam menghadapi berbagai gagasan modernisasi sehingga pesantren harus meningkatkan kuwalitas para santri-nya ke arah 
pemahaman dalam menguasai ilmu-ilmu agama, khusunya agama islam.

Tantangan-tantangan yang dihadapi dunia pendidikan dewasa ini telah menjadi semakin mengalami kompleksitas yang tinggi, dimana pendidikan di tuntut untuk menyesuaikan dirinya dengan keberadaan era sekarang (tahun 2021) dengan mensinergikan yang ada dalam dunia industri semisal pada ranah kemajuan teknologi dan juga integrasi teknologi yang semakin kilat dan cepat perkembangannya. Dalam ranah memodernisasi pendidikan Islam yang meliliki basis pendidikan karakter misalnya dewasa ini telah menjadi keniscayaan. Untuk itu kita sebagai manusia yang memiliki (otak) perlu berfikir kritis untuk menjawab tuntutan zaman, semisal dengan menciptakan pendidikan yang sesuai dengan kebutuhan yang ada di zaman generasi milenial seperti sekarang ini (Priyanto 2020, 0). Lebih lanjut (Ahyani, Permana, and Abduloh 2020, 0) dalam jurnalnya menyatakan bahwa di era 4.0 seperti sekarang ini terdapat dimensi-dimensi sosio kutural, yang mana pendidikan islam perlu dikembangkan sesuai tuntutan zaman, baik melalui transformasi-transformasi model pendidikannnya, atau hal lainnya.

Tantangan dunia pendidikan umum (perguruan tinggi) dicontohkan oleh Priyanto dalam risetnya bahwa pendidikan islam di zaman sekarang ini (era 4.0) wajib menjadi manusia yang unggul serta berdaya saing tinggi dimana manusia harus menjadi manusia yang kreatif, dan juga inovatif, serta menjadi manusia yang memiliki karakter (akhlak karimah), dan manusia di era 4.0 harus mampu mandiri, dan cinta terhadap tanah air dan manusia di era 4.0 harus mampu menguasai konsep religious dalam menghadapi Era yang canggih ini (4.0) di mana manusia dewasa ini dituntut untuk melakukan suatu gerakan yang serba cepat, tepat, efektif dan efisien, dalam bertindak tidak lelet (muntij) akan tetapi manusia di era 4.0 harus mustahliq (produktif) dan inovatif (Priyanto 2020).

Tantangan lainnya di era 4.0 pendidikan di lingkungan pesantren harus mampu tampil energik dimana pesantren tampil sebagai Lembaga Pendidikan Islam yang konsen dibidangnya serta mampu melakukan gebrakan atau pemberdayaan Umat khususnya mencetak insan kamil/manusia betaqwa dan berakhlaqul karimah (perilaku yang unggul) tidak terkecuali di Era Revolusi Industri 4.0 seperti sekarang ini. Di era 4.0 Pesantren juga harus selalu optimis jangan psimis, karena selama ini pesantren secara konsisten telah membuktikan kemampuannya dalam membentengi setiap pribadi santri terhadap derasnya arus yang dilontarkan oleh budaya Barat yang masuk ke wilayah NKRI (Indonesia) (Wiranata 2019).

Dari pembahasan peluang dan tantangan diatas maka dapat disimpulkan bahwa dalam penerapan model pendidikan perguruan tinggi di era 4.0 seperti sekarang ini di antaranya meliputi tantangan kultural budaya masyarakat indonesia, dan juga tantangan zaman yang kini perlu pensinergian pendidikan dalam hal teknologi. Pesantren perlu taqlid kepada zaman yang sedang dilaluinya, artinya pesantren sebagai lembaga pendidikan perlu asupan khusus meliputi berbagai kompetensikompetensi yang dimiliki para santri yang sedang menuntut ilmu, baik ilmu pesantren (agama) maupun ilmu yang didapat di perguruan tinggi yang ditugganginya.

\section{SIMPULAN}

Dari pembahsan diatas maka dapat disimpulkan bahwa perguruan tinggi yang ada di wilayah lokasi pesantren di era 4.0 melalui berbagai model yang ditawarkan dalam mempertahankan eksistensinya dapat dilakukan dengan cara memperkuat manajemen, tata kelola, dan sumber daya manusia yang ada di perguruan tinggi di Indoensia tanpa menghilangkan tradisi, budaya, kurikulum yang 
ada di pesantren yang menaungi perguruan tinggi tertentu. Bukti dari eksistensinya yang dilakukan oleh (perguruan tinggi di lingkungan pesantren) dapat dilakukan dengan cara melakukan inovasi-inovasi yang jitu dalam rangka mempertahankan kualitas perguruan tinggi salah satunya dengan digitalisasi perguruan tinggi yang sesuai dengan tuntutan zaman, semisal pemanfaatan media pembelajaran bagi mahasiswa (WA Group, Zoom Meet, Googl Meet), dalam hal penguatan SDM di perguruan tinggi dapat dilakukan dengan pemanfaatan aplikasi-aplikasi seperti SIAKAD, website, medsia sosial untuk pemasaran perguruan tinggi agar tetap eksis dalam mewujudkan Masyarakat Indonesia yang cerdas.

\section{DAFTAR PUSTAKA}

Adeng. 2011. "Sejarah Pesantren Miftahul Huda Manonjaya Tasikmalaya." Patanjala: Journal of Historical and Cultural Research 3 (1): 18-32. https://doi.org/10.30959/patanjala.v3i1.26 9.

Ahyani, Hisam, and Muharir. 2021. "Perspektif Hukum Ekonomi Syariah Tentang Wakaf Uang Di Era Revolusi Industri 4.0 | LAN TABUR: Jurnal Ekonomi Syariah." https://doi.org/10.1234/lan\%20tabur.v2i2.

Ahyani, Hisam, Muharir, and Dian Permana. 2020. "Philosophical Review Of Materialism And Idealism Married Age Limits In Indonesia (Study Of Article 7 Paragraph (1) Of Law 16 Of 2019 In Conjunction With Law 1 Of 1974 Concerning Marriage)." Al-IHKAM: Jurnal Hukum Keluarga Jurusan Ahwal al-Syakhshiyyah Fakultas Syariah IAIN $\begin{array}{llll}\text { Mataram } & 12 & \text { (2): } 107-24 .\end{array}$ https://doi.org/10.20414/alihkam.v12i2.3 048.

Ahyani, Hisam, Dian Permana, and Agus Yosep Abduloh. 2020. "Pendidikan Islam Dalam Lingkup Dimensi Sosio Kultural Di Era Revolusi Industri 4.0." Fitrah: Journal of Islamic Education 1 (2): 273-88.
Aryati, Seri. 2019. "Tantangan Perguruan Tinggi Di Era Revolusi Industri 4.0." Prosiding Seminar Nasional Program Pascasarjana Universitas Pgri $\begin{array}{lll}\text { Palembang } & 12 & \text { (01). }\end{array}$ https://jurnal.univpgri-

palembang.ac.id/index.php/Prosidingpps/ article/view/2639.

Athoillah, Muhammad Anton, and Elis Ratna Wulan. 2019. "Transformasi Model Pendidikan Pondok Pesantren Di Era Revolusi Industri 4.0.” Prosiding Nasional 2 (December): 25-36.

Darwis, Mohammad. 2020. "Revitalisasi Peran Pesantren Di Era 4.0." Dakwatuna: Jurnal Dakwah Dan Komunikasi Islam 6 (1): 128-37. https://doi.org/10.36835/dakwatuna.v6i01 .509 .

Harususilo, Yohanes Enggar. 2021. "Ini Beda Universitas, Institut, Sekolah Tinggi, Politeknik, Dan Akademi: Pnj.Ac.Id: Politeknik Negeri Jakarta | PNJ.” 2021. https://pnj.ac.id/readmore/6003c638fd22e 6582a2f6762/ini-beda-universitasinstitut-sekolah-tinggi-politeknik-danakademi.

Isbah, M. Falikul. 2020. "Pesantren in the Changing Indonesian Context: History and Current Developments." QIJIS (Qudus International Journal of Islamic Studies) $\quad 8$ (1): 65-106. https://doi.org/10.21043/qijis.v8i1.5629.

Manan, Muhamad Abdul. 2019. "Daya Tahan Dan Eksistensi Pesantren Di Era 4.0." Jurnal Pendidikan Islam Indonesia 3 (2): 155-67 https://doi.org/10.35316/jpii.v3i2.135.

Nizar, Samsul. 2013. Sejarah Sosial Dan Dinamika Intelektual Pendidikan Islam Di Nusantara. Jakarta: Kencana.

Nurcholiq, Mochamad. 2019. "Desain Pengembangan Kurikulum Madrasah Aliyah Unggulan Di Era Revolusi Industri 4.0." Piwulang: Jurnal Pendidikan Agama Islam 1 (2): 208-22. https://doi.org/10.32478/piwulang.v1i2.2 47.

Nurmalasari, Neneng, and Imas Masitoh. 2020a. 
Hikmah, Vol. 18, No. 1, Januari-Juni 2021, p-ISSN: 1829-8419 e-ISSN: 2720-9040

"Manajemen Strategik Pemasaran Pendidikanberbasis Media Sosial." International Journal of Management Reviews Volume 4 Number 3.

Nurmalasari, 2020b. "Manajemen Strategik Pemasaran Pendidikan Berbasis Media Sosial di Madrasah Aliyah Yayasan Pondok Pesantren Babakan Jamanis Parigi Pangandaran." Re-JIEM (Research Journal of Islamic Education Management) 3 (2): $120-28$. https://doi.org/10.19105/rejiem.v3i2.3908.

Pangandaran, Post. 2021. "KPU Pangandaran dan STITNU Al Farabi Tandatangani MoU Sebagai Bentuk Jalin Kerjasama." Post Pangandaran. 2021. https://postpangandaran.com/plugin/articl e/view/723/kpu-pangandaran-dan-stitnual-farabi-tandatangani-mou-sebagaibentuk-jalin-kerjasama.

Permana, Dian, and Hisam Ahyani. 2020. "Implementasi Pendidikan Islam Dan Pendidikan Multikultural Pada Peserta Didik.” Jurnal Tawadhu 4 (1): 995-1006.

Permana, Dian Dwi. 2011. "Model Pembelajaran Moral dalam Kegiatan Thoriqoh Naqsabandyah Kholidiyah al Aliyah Bagi Santri Di Pondok Pesantren Baiturrohmah Malang / Dian Dwi Permana." Diploma, Universitas Negeri Malang.http://repository.um.ac.id/51554/.

Priyanto, Adun. 2020. "Pendidikan Islam dalam Era Revolusi Industri 4.0." J-PAI: Jurnal Pendidikan Agama Islam 6 (2). https://doi.org/10.18860/jpai.v6i2.9072.

Rukanda, Heru. 2021. "Profil Pesantren: Ciri Khas Ponpes Miftahul Huda Manonjaya 'Sorogan' Kitab Kuning." AyoTasik.com. 2021.

http://www.ayotasik.com/read/2021/03/1 9/9213/profil-pesantren-ciri-khas-ponpesmiftahul-huda-manonjaya-sorogan-kitabkuning.

Sevima, Admin. 2018. "Permudah Perlaporan Ke PDDikti \& DIKTIS, STAIMA Banjar Pakai GoFeeder Cloud." PT. Sentra Vidya Utama. September 27, 2018. https://sevima.com/permudah-perlaporanke-pddikti-diktis-staima-banjar-pakaigofeeder-cloud/.

Shofiyyah, Nilna Azizatus, Haidir Ali, and Nurhayati Sastraatmadja. 2019. "Model Pondok Pesantren di Era Milenial." Belajea; Jurnal Pendidikan Islam 4 (1): 1-18. https://doi.org/10.29240/belajea.v4i1.585.

Sukoco, Iwan, Dian Fordian, and Rusdin. 2019. "Model Manajemen Perguruan Tinggi Pada Program Studi Di Luar Kawasan Utama (PSDKU) Dan Tingkat Kepuasan Mahasiswa. (Studi Kasus di PSDKU Unpad Pangandaran Jawa Barat)." AdBispreneur: Jurnal Pemikiran dan Penelitian Administrasi Bisnis dan Kewirausahaan 3 (3): 251-71. https://doi.org/10.24198/adbispreneur.v3i 3.19577 .

Tabroni, Imam, Hisam Ahyani, and Dian Permana. 2021. "Philosophical Review of Materialism and Idealism Limits of Wedding Age in Indonesia; Study of Article 7 Paragraph (1) of Law 16 of 2019 Jo. Law 1 of 1974 Concerning Marriage." Muttaqien: Journal of Multidiciplinary Islamic Studies 2 No 1. https://doi.org/10.20213/mtq.02.1.01.

Wiranata, Rz Ricky Satria. 2019. "Tantangan, Prospek Dan Peran Pesantren Dalam Pendidikan Karakter di Era Revolusi Industri 4.0." Al-Manar 8 (1): 61-92. https://doi.org/10.36668/jal.v8i1.99. 